\title{
College Fund Raising Using Theoretical Perspectives to Understand Donor Motives
}

Received (in revised form): March 3, 2007

\section{Timothy Mann}

until recently served as the Dean of Student Affairs at Babson College. He holds a B.A. in Public Administration from the University of Windsor in Ontario, Canada and an M.S. in College Student Personnel from Northeastern University in Boston, MA. He is currently a Ph.D. candidate in the Law, Policy and Society program at Northeastern University.

\section{Abstract}

This paper provides senior leadership teams with a body of literature that will guide the development of fundraising strategy and provides an interdisciplinary context for understanding donor motives. Consideration of these theoretical foundations can help shape the fundraising philosophy of the institution. These perspectives also have practical implications on the interactions between the College and its alumni including how the College communicates with alumni or how donors are recognized for their generosity.

International Journal of Educational Advancement (2007) 7, 35-45. doi:10.1057/palgrave.ijea.2150042

Keywords:

fund raising, strategy, donor motives

Author's Contact Address:

Timothy Mann

Babson College

Babson Park,

MA 2457, USA

Phone: +1 7812394218

Fax: +1 7812395535

E-mail: mann@babson.edu or mann.t@neu.edu

\section{Introduction}

Fund-raising efforts at college and universities continue to be a top priority. It is clear that an institution's ability to realize their innovative but costly strategic goals is directly dependant on their ability to generate donations from alumni, foundations, friends, parents, and other institutional partners. The reliance on fund-raising dollars is even more pronounced due to the rising public scrutiny of the cost of higher education (Farrell, 2003; Trompley, 2003; US Department of Education, 2006).

The theoretical perspectives outlined in this paper provide a structural framework to guide fund-raising philosophy. By viewing advancement programs through a theoretical lens, fundraisers may benefit from examining existing practices through a series of questions:

1. Which theoretical perspectives most accurately reflect our donor's motives for giving?

2. Do different theories apply to different alumni cohorts?

3. Does our alumni communication and external relations align with this theory(s)? 
4. What can we change to more effectively align our fund-raising strategy with what motivates or influences different donors on our campus?

\section{Theoretical Context}

In philanthropic literature, altruism is often referenced as a primary motive for why individuals make donations to a particular cause or charity. In the campus setting, it is argued that an individual's experience while attending college creates a special sense of obligation that results in a donation being made to their alma mater. ${ }^{1}$ The notion of altruism has developed into a loosely organized theory of charitable giving that embraces some tenets from volunteerism and elements of charitable economics literature.

While this theory provides one perspective for why some individuals make donations, it does not account for other contributing bodies of literature that provide a more comprehensive understanding of philanthropic motives. Rose-Ackerman (1996) for example, believes that altruism and nonprofit entrepreneurship cannot be understood within a standard economic framework. She goes on to state that to better understand the variables that motivate individuals to make a donation, further inquiry is needed in the areas of organizational behavior and the voluntary sector. Olson (1965) suggests that individuals are sometimes motivated by a desire to win prestige, respect, friendship, and other social and psychological objectives (p. 60), while Becker (1974) finds that apparent charitable behavior can also be motivated by a desire to avoid the scorn of others or to receive social acclaim (p. 1083).

There is a strong interdisciplinary body of literature that when contrasted and coordinated, provides for a broader understanding of what motivates people to give. Philanthropy cannot be viewed in the context of a single field or discipline. Rather, some may describe it more as an art than representing one specific academic or vocational focus.

Development efforts are intended to improve the quality of life of its beneficiaries and because of its broad and virtuous goals, philanthropy is embedded throughout many traditional scholarly areas including organizational behavior, sociology, economics, consumer behavior, and marketing and sales. Fig. 1 illustrates the diverse theoretical perspectives that are critical to understanding philanthropy and how it is woven into the fabric of several scholarly disciplines.

Consequently, it is important to consider an inter-theoretical framework from which to understand the connectedness of philanthropic efforts stemming from multiple disciplines.

\section{Summary of Theoretical Perspectives}

An overview of diverse theoretical literature may assist advancement efforts in evaluating the alignment of fund-raising programs, alumni relations, and external outreach efforts with an understanding of how and what motivates donors to be charitable to their alma mater. Table 1 provides a summary of these theoretical perspectives and their potential 
Table 1: Summary of theoretical perspectives

$\begin{array}{ll}\text { Theory Characteristics } & \text { Fundraising considerations }\end{array}$

Charitable giving

Organizational identification

Social identification

Economics

Services-philanthropic

Relationship-marketing
There are three motivations to explain why people make donations: (1) altruism, (2) reciprocity, and (3) direct benefits; altruism is a primary motive in explaining why individuals make donations to a particular cause or charity

People define themselves (in part) by their association with the organization; they feel a strong connection to the organization; proud parent phenomenon; celebrate the organizations successes (i.e. achieving important goals)

A person's identity is influenced by how they order themselves into social groups or categories; their socia identity evolves from their ordering; people develop a deep psychological connection to that group (i.e. class of students, roommates, athletic team)

Donors feel utility in making a gift that benefits the recipients; the more apparent the need, the more motivated they are to make a donation

\section{People's behavioral intent is} influenced by three constructs: (1) service value, (2) service quality, and (3) satisfaction; these constructs shape a person's overall experience and perception of an organization

$$
\begin{aligned}
& \text { Customers have relationships } \\
& \text { with an organization ranging } \\
& \text { from transactional to highly } \\
& \text { relational; customers who have a } \\
& \text { positive relationship feel connected } \\
& \text { to the organization, whereas } \\
& \text { transactional customers view their } \\
& \text { relationship as an exchange of } \\
& \text { services and have no emotional } \\
& \text { investment in the } \\
& \text { organization }
\end{aligned}
$$

\begin{abstract}
Alumni feel a sense of obligation towards alma mater; have pride in their association with their College; alumni feel a responsibility to make donations
\end{abstract}

Alumni who feel connected to the College as an organization will celebrate the achievement of its strategic and fund-raising goals; they will be inclined to support these goals and be motivated to be a donor
Alumni maintain positive psychological connections to a group(s) from their College experience; fund-raising efforts can focus on group-specific goals to motivate alumni to make donations (i.e. hockey team, debate team)

When a potential donor better understands the need or value for gift, there is an increased likelihood that they will make a gift

When alumni feel they receive professional service and value from their alma mater, they are likely to have a more positive perception of the organization and its fund-raising needs

Effective communication with alumni will help shape a positive relationship between the College and the alumnus; Conversely, poor communication will shape the relationship as more transactional; developing positive relationships between alumni and their College will create an emotional connection that may support fund-raising efforts 
implications for fund-raising.

Following this summary is a more detailed review of each perspective.

\section{Charitable giving theory}

Throughout the charitable giving literature, there are references to three possible motivations that explain why people give. These are (1) altruism, (2) reciprocity, and (3) direct benefits (Bruggink and Siddiqui, 1995). The benefit of this particular body of literature is that it is crafted in a language that fits directly into the field and practice of fund-raising and philanthropy. Consequently, it provides a clear premise that is applicable and understandable. ${ }^{2}$

The first motivation for giving states that individuals have altruistic preferences to their alma mater. This may be driven by a social sense of obligation to provide collective goods and services to society. In addition, the sense of obligation is further enhanced by strong feelings of allegiance and empathy towards the college (Bruggink and Siddiqui, 1995). Advancement teams are acutely aware of this "altruistic opportunity" and organize fund-raising efforts around such events as reunions, college anniversaries, and campaign goals.

The second motivation refers to the notion of reciprocity. Reciprocity is the belief that the motivation for an individual to make a gift is based on the potential return of some benefit. Mauss (1954) concludes that giftgiving is a self-perpetuating system of reciprocity which includes three types of obligations that impact gift-giving. These three obligations include (1) the obligation to pay, (2) the obligation to receive, and (3) the obligation to repay.
As Bruggink and Siddiqui point out, this is easily understood in a setting like a church. Members of the congregation make a regular gift during the offering and in return receive the perceived benefit of a quidpro-quo relationship with an active church that provides both a spiritual and community benefit for their family. From a college perspective, it is more difficult to create a universal benefit comparison for all alumni based on the reality that each alumnus will have different degrees of allegiance to the college based on a number or variables including involvement in campus activities, academic success, employment success post graduation, and their geographic location relative to the campus.

The third motivation, direct benefits, refers to the advantages to growing or improving the brand value and reputation of their college and any resulting benefits that may come to them as a result. Such benefits could include a reference to their role in a prominent college publication, physical spaces being named in their honor or invitations to speak at high profile events on campus or on behalf of the college, or the perceived value of being associated (as alumni) with a college whose reputation is enhanced through vigorous alumni support.

\section{Organizational identification theory}

Organizational identification theory is a critical piece of literature in the development of organizational behavior research. Institutions can examine why individuals feel a very high level of connectedness to the organization, or more specifically their 


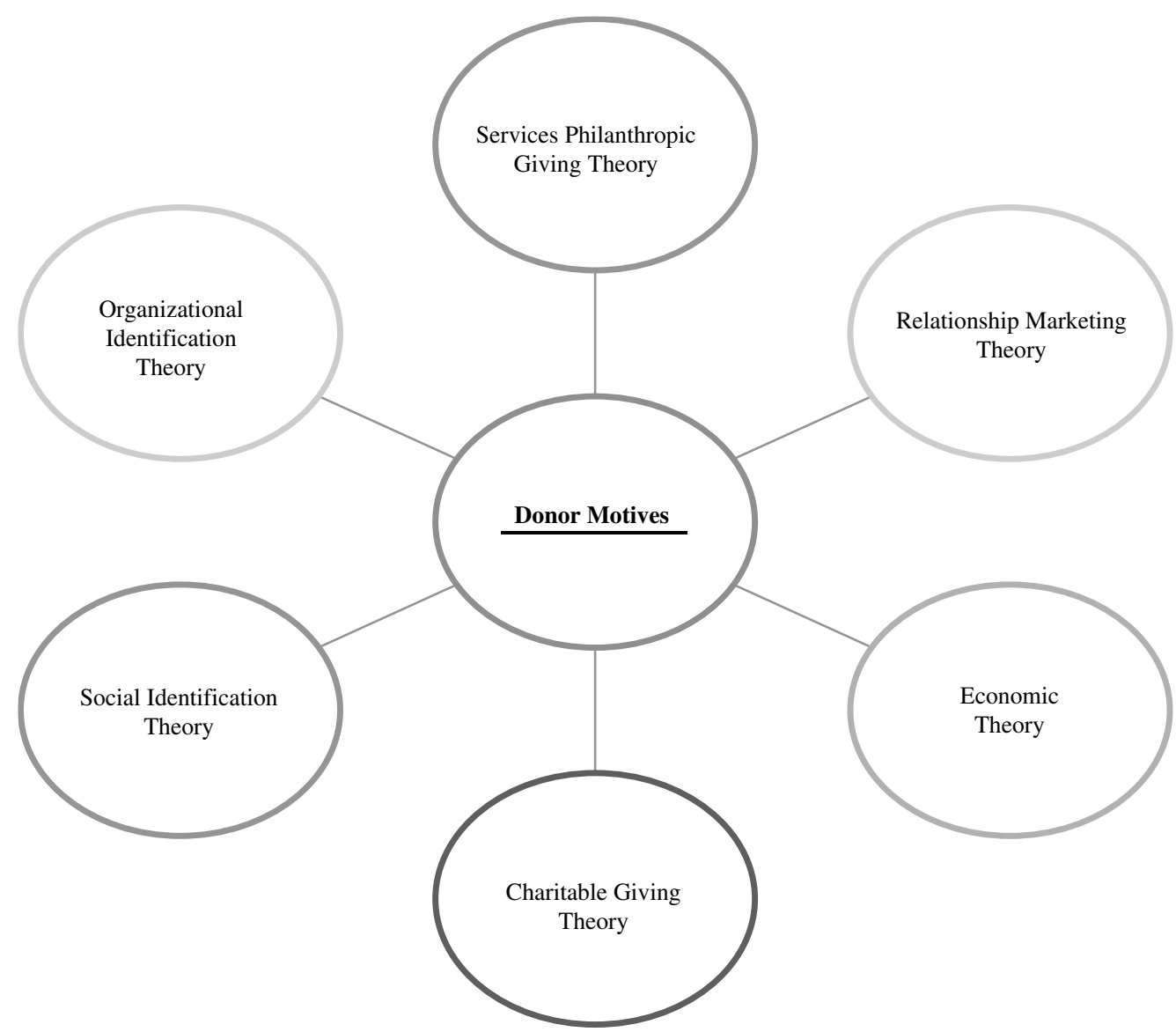

Figure 1: Theoretical framework for understanding donor motives

alma mater. Organizational

identification is defined as "the perception of oneness with or belongingness to an organization, where the individual defines themselves in terms of the organizations(s) in which he or she is a member" (Mael and Ashforth, 1992). Individuals who feel a strong connection to the organization will celebrate the successes that the organization achieves but also will be concerned when a weakness or failure is exposed. Not unlike a proud parent, the individual is very proud of the organization and what it stands for. ${ }^{3}$
The organizational identification literature was later supplemented by Bhattacharya et al. in 1995. In their work they suggested the development of a model that correlates an individual's identification with the organization with a number of factors. These factors include "organizational and product factors, member's affiliation characteristics and member's activity characteristics" (p. 46). According to their study, members who were actively involved during their studies, such as being a member of an athletic team or Greek organization, may develop a strong 
bond to the College and therefore have a greater propensity to make a donation.

The consideration of organizational identification theory in college fundraising is significant because it provides a rationale explanation of why people make donations. Young (1981, p. 81) suggests five key reasons why individuals make donations to their alma mater. They include “(1) selfgenerated convictions as to the institution's merits (2) objectives and plans of the institution (3) efficiency of the institution (4) competence of the institution's leadership and (5) tax advantages." Ashforth and Mael (1989) contend that this theory presents some limitations because research efforts "have often confused organizational identification with related constructs such as organizational commitment and internalization and with affect and behaviors, which are more appropriately seen as antecedents and/or consequences of identification" (p. 20).

\section{Social identification theory}

Social identification theory is based on the premise that each person's self concept is a combination of two components (Tajfel and Turner, 1985). The first component is one's personal identity that includes idiosyncratic characteristics such as abilities and interests. The second component is one's social identity that includes salient group classification. This theory suggests that individuals have a tendency to order themselves into a variety of social groups which includes organizational membership, gender, and age. Therefore, social identification is how individuals perceive themselves as members of a particular social group or category. ${ }^{4}$ Such identification in a college setting may manifest itself through statements like "I was a member of the baseball team" or "I was a Resident Assistant on lower campus." According to Ashforth and Mael (1989), there are two important roles that social classification provides. First, it cognitively segments and orders the social environment, providing it with a systematic means of defining others. A person is assigned the prototypical characteristics of the category to which he or she is classified. The second role is that social classification enables the individual to locate or define him or herself in the social environment. "The self-concept is comprised of a personal identity encompassing idiosyncratic characteristics (e.g. bodily attributes, psychological traits, interests) and a social identity encompassing salient group classifications” (p. 20).

There are four emerging principles from the literature that help explain the role this theory has in understanding group identification. The first principle views social identification as "a perceptual cognitive construct that is not necessarily associated with any specific behaviors or affective states" (Ashforth and Mael, 1989, p. 21). Foote (1951) suggested that to identify with a group, an individual need not expend effort toward the group's goals. Instead, an individual need only perceive him or herself as psychologically intertwined with the fate of the group. Behavior and affect are viewed only as potential antecedents or consequences.

The second principle is the perspective that social identification is 
seen as personally experiencing the successes and failures of the group (Tolman, 1943; Foote, 1951). Frequently, the social identification one has with a group is maintained in situations involving great loss or suffering (Brown et al., 1986).

The third principle describes social identification as distinctly different from internalization (Hogg and Turner, 1987). Identification looks at the self in terms of social categories, whereas internalization refers to the integration of values, attitudes, and interests within the self as guiding principles. It is an important distinction because it highlights the plausible situation where an individual may define his or herself in terms of the organization and yet she or he can disagree with the prevailing values, strategy, power structure, ethics, and overall direction that organization is going (Martin and Siehl, 1983, p. 22).

The final principle states that identification with a group is not unlike the way an individual identifies with a person such as a parent, teacher, or sports figures or as one identifies with a role within an existing relationship such as a brother and sister or husband and wife. Ashforth and Mael (1989) point out that the literature comes to this conclusion from different perspectives. "Whereas identification with a group is argued to be predicated on the desire for self-definition, identification with an individual is argued to be predicated on the desire to appease, emulate or vicariously gain the qualities of the other" (Kets de Vries and Miller, 1984).

\section{Economic theory}

The economics literature is rich with research but unfortunately the studies and analyses do not neatly fit into a model of philanthropy and understanding why people make donations. The economic literature that references charity has developed out of the theory of consumer demand for nondurable goods and services (Okunade et al., 1994). This approach relies on the price and income effects of making voluntary charitable gifts. This model examines the impact of how individuals make contributions in relationship to changes in tax policy (Feldstein, 1975; Hood et al., 1977).

The market forces surrounding consumer motives and the traditional nexus of supply and demand theory are more difficult to apply to philanthropic initiatives. Consequently, economists attempt to analyze philanthropy from the perspective of an interdependent utility thesis. Harrison et al., (1995, p. 398), suggest that a potential donor is motivated to give as a result of the impact the gift has on others.

In economic terms, the utility that the recipients or beneficiaries of the gift experience is what directly influences the donor to make the gift. "The altruistically motivated individual is one who has a high need for nurturance (the motivational need to give to others) and a low need for succorance (the motivational need to receive from others)" (Freeman, 2004). The more apparent the need for a donation, the more motivated the donor is to make a gift. ${ }^{5}$

In the higher education environment, an extension of this economic theory suggests that there is a market force which attempts to achieve a mutual satisfaction of needs. The market forces include a framework that would have alumni supply donations to their 
alma mater, and in turn, would provide recognition to those that made gifts.

Freeman (2004) suggests that there are two variables that determine why people participate in volunteer activities. The first variable is based on how and if people value the specific charity. The second variable is whether the request carries some perceived social "pressure" (i.e. other members of your class have made donations to sponsor a faculty endowed chair at your alma mater). The variable suggests that people feel or get pressured into giving when asked but it they had not been asked, they probably would never give. Freeman indicates that this concept of why people volunteer requires more research and has been neglected by economists.

\section{Services-philanthropic giving theory}

This is a relatively recent and hybrid model that suggests a person's behavioral intent is influenced by three primary constructs (1) service value, (2) service quality, and (3) satisfaction. These constructs are then blended with a person's intent to give which then directs the focus to the philanthropic landscape.

Service value is defined as the tradeoffs that consumers make between what they receive (quality, benefits, utility) and what they give up to acquire these benefits (Monroe, 1990; Gale, 1992). This value is a perceived emotion rather than something that is objectively determined (Woodruff, 1997). Donors assess the perceived quality of the charitable organization and compare it to the relative size of their contribution.

Service quality refers to how the potential donor perceives the quality of operations and service that they receive by the organization. On a transaction level, the interaction that the donor has with the organization often determines their perception of service quality. At the macro level, service quality refers to the perception of how effective the organization is in implementing its strategic plan and accomplishing its goals (Bitner and Hubbert, 1994).

Satisfaction describes the overall quality of the donor's experience with the organization. A donor's satisfaction is related to their perception of the overall service quality and value received from the organization (Fornell et al., 1996). Perceived quality may develop through the influence of external or environmental factors such as other peoples reported experiences, written information or opinions (Brady and Cronin, 2001).

Service-related influences on giving are different from philanthropic influences. Service-related influences focus on the perceived quality, value, and satisfaction related to the individuals' perception of their experience with the organization and their assessment of the value of the relationship. Alternatively, philanthropic influences focus on a different set of variables such as donor's ability to give, propensity to give or judgments of the organizations need for giving (Brady et al., 2002, p. 4).

\section{Relationship-marketing theory}

A key goal of relationship-marketing theory is the identification of key drivers that influence important outcomes for the organization and a better understanding of the causal relationship between these drivers and 
outcomes (Hennig-Thurau et al., 2002, p. 231). The basic premise of relationship-marketing theory is that customers vary in their relationships with an organization on a continuum from transactional to highly relational bonds (Garbarino and Johnson, 1999). Throughout the literature there have been a number of terms describing relationship-marketing including strategic partnering, strategic alliances, "friend-raising," and network organizations. Regardless of the term, the concept remains relatively constant. The focus is on cultivating and sustaining positive relationships between an organization and its key constituent groups. In the case of a college campus, those groups include alumni, governance, corporations, "friends," and foundations.

Communication is a key variable that impacts relationship-marketing. The greater the communication between the organization and the customer, the stronger the correlation between the development of closer relationships and the overall satisfaction of the parties involved (Cannon and Homburg, 2001; McAlexander and Koenig, 2001).

In a for-profit setting, relationshipmarketing activities are ultimately evaluated on the basis of the organization's profitability. In a nonprofit organization, the success of relationship marketing activities may be measured based on first time giving, repeat giving or overall participation in fund-raising efforts at all levels of the program. In either case, there are two constructs referred to in the marketing literature that are described as key relationship-marketing outcomes. These are (1) customer loyalty and (2) customer word-of-mouth communication (Hennig-Thurau et al., 2002). Customer loyalty focuses on a customer's repeat purchase behavior that is triggered by a marketer's activities. Customer word-of mouth communication is referred to as informal communication that takes place between a customer and others concerning the evaluation of goods and services. This can include relating pleasant, vivid, or novel experiences, or recommendations to others (Anderson, 1998, p. 6). This form of communication is viewed as being very reliable and represents a powerful force in influencing future buying decisions, particularly when the service delivered is of high risk for the customer (Sheth et al., 1999).

\section{Conclusion}

It is important that advancement teams consider the theoretical context in order to sharpen and test their understanding of what motivates alumni to donate. Effective fundraising strategy, in its formative stages, should be securely grounded in a clear theoretical foundation. Such a foundation may vary based on the unique institutional culture and characteristics of each campus.

Connecting fund-raising strategy to a theoretical base is easily overlooked as senior leadership teams frequently turnover and quickly narrows their focus on campaign goals, fund-raising targets, or major prospects. Are alumni of College X motivated to make a donation because of how they identify with the reputation of the College? Do alumni of University $\mathrm{Y}$ make donations because they identify with an experience they had or a group of peers or program they are passionate about? Or, do alumni make donations 
because they feel a certain obligation or pressure to contribute. Responding to these questions should be facilitated in the context of theoretical perspectives that motivate people to be philanthropic.

Most colleges and universities are reliant on fund-raising efforts to pursue strategic initiatives and to balance operating budgets. The competition for each philanthropic dollar is greater than ever as nonprofit organizations become more effective and organized in their fund-raising efforts, as the number of nonprofit organizations increase and as more national or international "crisis" causes (September 11th, Tsunami relief, Hurricanes Katrina and Rita) organize and successfully garner private support from individual donors. With more complex and sophisticated competition, college and universities must focus on determining the most effective ways to connect with their alumni base to create a life long partnership.

\section{Notes}

${ }^{1}$ This is a counter theory to the altruistic value of giving. This counter theory is referred to as the "warm glow giving" theory and states that social pressure, guilt, sympathy, or simply a desire for a warm glow may play important roles in the decisions of potential donors (Andreoni, 1990).

${ }^{2}$ It has been suggested by Andreoni (1990) that using this theoretical model which relies on altruism as a key ingredient may lack predictive power. ${ }^{3}$ It has also been argued by O'Reilly and Chatman (1986) that this proud parent phenomenon is an important factor in supporting the well being of staff members who work for the organization. ${ }^{4}$ Some research would argue that the prototypical labels or stereotypes are not reliable and therefore may be inappropriately relied upon in the theoretical context (see Hamilton, 1981).

${ }^{5}$ Conversely, it has been noted that a donor's inclination to make a gift is diminished if the object of philanthropy is already wealthy or the overall need does not appear to be significant as other potential needs (see Becker, A theory of social interactions, Journal of Political Economy, 1974).

\section{References}

Anderson, E.W. (1998), "Customer satisfaction and word of mouth," Journal of Service Research, 1, pp. 5-17.

Andreoni, J. (1990), "Impure altruism and donations to public goods: A theory of warm-glow giving," Economic Journal, 100, pp. 464-477.

Ashforth, B.E. and Mael, F. (1989), "Social identity theory and the organization," Academy of Management Review, 14, 1, pp. 20-39.

Becker, G.S. (1974), “A theory of social interaction," Journal of Political Economy, 83, 6, pp. 1063-1093.

Bhattacharya, C.B., Hayagreeva, R. and Glynn, M.A. (1995), "Understanding the bond of identification: An investigation of its correlates among art museum members," Journal of Marketing, 59, pp. 46-57.

Bitner, M.J. and Hubbert, A.R. (1994), "Encounter satisfaction versus overall satisfaction versus quality", in R.T. Rust and R. L. Oliver (eds.), Service Quality: New Directions in Theory and Practice, Sage, Thousand Oaks, CA.

Brady, M.K. and Cronin, J.J. (2001), "Some new thought on conceptualizing perceived service quality: A hierarchical approach," Journal of Marketing, 65, pp. 34-49.

Brady, M.K., Noble, C.H., Utter, D.J. and Smith, G.E. (2002), "How to give and receive: An exploratory study of charitable hybrids," Psychology and Marketing, 19, 11, pp. 919-932.

Brown, R., Condor, S., Mathews, A., Wade, G. and Williams, J. (1986), "Explaining intergroup differentiation in an industrial organization," Journal of Occupational Psychology, 59, pp. 273-286. 
Bruggink, T.H. and Siddiqui, K. (1995), “An econometric model of alumni giving: A case study for a liberal arts college," The American Economist, 2, pp. 53-60.

Cannon, J.P. and Homburg, C. (2001), "Buyer supplier relationships and customer firm costs," Journal of Marketing, 65, pp. 29-43.

Farrell, E. (2003), "Public-College tuition rise is largest in 3 decades," The Chronicle of Higher Education, October 31, Retrieved from www. chronicle.com.

Feldstein, M. (1975), "The income tax and charitable contributions; Part I-aggregate and distributional effects," National Tax Journal, 28, pp. 81-100.

Foote, N.N. (1951), "Identification as the basis for a theory of motivation," American Sociological Review, 16, pp. 14-21.

Fornell, C., Johnson, M.D., Anderson, E.W., Cha, J. and Bryant, B.R. (1996), "The American customer satisfaction index: Nature, purpose and findings," Journal of Marketing, 60, pp. 7-18.

Freeman, K (2004), "Motivational needs and interdependent utilities," International Journal of Social Economics, 31, 5/6, pp. 561-571.

Gale, B. (1992), Monitoring Customer Satisfaction and Market-Perceived Quality, Worth Repeating Series, No. 922CS01, American Marketing Association, Chicago.

Garbarino, E. and Johnson, M.S. (1999, April), "The different roles of satisfaction, trust and commitment in customer relationships," Journal of Marketing, 63, pp. 70-87.

Hamilton, D.L. (ed.), (1981), Cognitive Processes in Stereotyping and Intergroup Behavior, Erlbaum, Hillsdale, NJ.

Harrison, W.B., Mitchell, S.K. and Peterson, S.P. (1995), “Alumni Donations and Colleges' Development Expenditures: Does Spending Matter?," Journal of Economics and Sociology, 54, 4, pp. 397-412.

Hennig-Thurau, T., Gwinner, K.P. and Gremier, D.D. (2002), "Understanding relationship marketing outcomes; An integration of relational benefits and relationship quality," Journal of Service Research, 4, 3, pp. 230-247.

Hogg, M.A. and Turner, J.C. (1987), "Interpersonal attraction, social identification and psychological group formation," European Journal of Social Psychology, 15, pp. 51-66.

Hood, R.D., Martin, S.A. and Osberg, L.S. (1977), "Econometric determinants of individual charitable donations in Canada," Canadian Journal of Economics, 10, pp. 653-669.

Kets de Vries, M.F.R. and Miller, D. (1984), The Neurotic Organization: Diagnosing and Changing Counterproductive Styles of Management, Jossey-Bass, San Francisco.
Mael, F. and Ashforth, B.E. (1992), "Alumni and their alma mater: A partial test of the reformulated model of organizational identification," Journal of Organizational Behavior, 13, 2, pp. 103-123.

Martin, J. and Siehl, C. (1983), "Organizational culture and counterculture: An uneasy symbiosis," Organizational Dynamics, 12, 2, pp. 52-64.

Mauss, M. (1954), in I. Cunnison (trans.), The Gift: Forms and Functions of Exchange in Archaic Societies, Cohen \& West, London.

McAlexander, J.H. and Koenig, H.F. (2001), "University experiences, the student college relationship and alumni support," Journal of Marketing for Higher Education, 10, pp. 21-43.

Monroe, K.B. (1990), Pricing: Making Profitable Decisions 2nd edn., McGraw Hill, New York.

Okunade, A.A., Wunnava, P.V. and Walsh, R. (1994), "Charitable giving of alumni: Micro data evidence from a large public university," The American Journal of Economic and Sociology, 53, 1, pp. 73-84.

Olson, M. (1965), The Logic of Collective Action, Harvard University Press, Harvard.

O'Reilly\#\#III, C. and Chatman, J. (1986), "Organizational commitment and psychological attachment: The effects of compliance, identification and internalization on prosocial behavior," Journal of Applied Psychology, 71, pp. 492-499.

Rose-Ackerman, S. (1996), "Altruism, nonprofits, and economic theory," Journal of Economic Literature, 34, pp. 701-728.

Sheth, J.N., Mittal, B. and Newman, B.I. (1999), Consumer Behavior: Consumer Behavior and Beyond, Dryden Press, Forth Worth, TX.

Tajfel, H. and Turner, J.C. (1985), "The social identity theory of intergroup behavior", in S. Worchel \& W.G. Austin (eds.), Psychology of Intergroup Relations, Nelson-Hall, Chicago.

Tolman, E.C. (1943), "Identification and the postwar world," Journal of Abnormal and Social Psychology, 38, pp. 141-148.

Trompley, W. (2003, Winter), College Affordability in Jeopardy; The Rising Price of Higher Education, The National Center for Public Policy and Higher Education, Washington, DC.

United States Department of Education (2006), "A test of leadership: Charting the future of U.S. higher education," A Report of the Commission Appointed by Secretary of Education, Margaret Spellings, Washington, DC.

Woodruff, R.B. (1997), "Customer value: The next source for competitive advantage," Journal of the Academy of Marketing Science, 25, pp. 139-153.

Young, C.F. (1981), "Interests and motives of nonalumni givers", in F.C. Pray (ed.), Handbook for Educational Fundraising, Jossey-Bass, San Francisco, CA, pp. 73-81. 